Proc. Estonian Acad. Sci. Biol. Ecol., 2005, 54, 4, 255-270

\title{
Estonian Enchytraeidae (Oligochaeta) 2. Results of a faunistic workshop held in May 2004
}

\author{
Rüdiger M. Schmelz ${ }^{\mathrm{a}}$, Naime Arslan ${ }^{\mathrm{b}}$, Roswitha Bauer ${ }^{\mathrm{c}}$, Wim Didden ${ }^{\mathrm{d}}$, \\ Klára Dózsa-Farkas ${ }^{\mathrm{e}}$, Ulfert Graefe ${ }^{\mathrm{f}}$, Irina Panchenko ${ }^{\mathrm{g}}$, Andrei \\ Pokarzhevski $^{\mathrm{g}}$, Jörg Römbke ${ }^{\mathrm{h}}$, Jiři Schlaghamerský ${ }^{\mathrm{i}}$, Łukasz Sobczyk ${ }^{\mathrm{j}}$, \\ Zoltán Somogyi ${ }^{\mathrm{k}}$, Valerie Standen ${ }^{1}$, Astrid Thompson ${ }^{1}$, Jānis Ventinšs ${ }^{\mathrm{m}}$, \\ and Tarmo Timm ${ }^{\mathrm{n}^{*}}$
}

${ }^{\text {a }}$ Department of Animal Biology, Plant Biology and Ecology, Faculty of Sciences, University of La Coruña, Alejandro da Sota 1, 15008 La Coruña, Spain

${ }^{\mathrm{b}}$ Biology Department, Science \& Art Faculty, Osmangazi University, Meselik, Eskişehir, TR-26480, Turkey

${ }^{c}$ Institut für Zoologie, Universität für Bodenkultur, Gregor-Mendel-Str. 33, A-1180 Wien, Austria. Liniengasse 47/6, A-1060 Wien, Austria

${ }^{\mathrm{d}}$ Department of Soil Quality, Wageningen University, P.O. Box 8005, 6700 EC Wageningen, The Netherlands

e Department of Systematic Zoology and Ecology, Eötvös Loránd University, Pázmány Péter sétany 1/C, H-1117 Budapest, Hungary

${ }^{\mathrm{f}}$ Institut für Angewandte Bodenbiologie GmbH, IFAB, Sodenkamp 62, 22337 Hamburg, Germany

g Institute of Ecology and Evolution of the RAS, Leninskij prospect 33, 119071 Moscow, Russia

${ }^{\text {h }}$ ECT Oekotoxicologie GmbH, Böttgerstr. 2-14, D-65439 Flörsheim, Germany

i Department of Zoology and Ecology, Faculty of Science, Masaryk University, Kotlarská 2, CZ-611 37 Brno, Czech Republic

j Department of Ecosystem Study, Institute of Environmental Sciences, Jagellonian University, Kraków, Poland

${ }^{k}$ Department of Zoology and Ecology, Szent István University, Páter Károly utca 1, 2103 Gödöllő, Hungary

${ }^{1}$ Department of Biology and Biomedical Sciences, Durham University, South Road, Durham, DH1 3LE, U.K.

${ }^{\mathrm{m}}$ Faculty of Geography and Earth Sciences, Latvian University, Alberta 10, Riga 1010, Latvia

${ }^{n}$ Centre for Limnology, Institute of Agricultural and Environmental Sciences, Estonian Agricultural University, 61101 Rannu, Tartumaa, Estonia

Received 30 November 2004, in revised form 5 April 2005

\begin{abstract}
This paper contains the results of a taxonomic workshop held at the Vortsjärv Limnological Station on 15-22 May 2004, following the 6th International Symposium on Enchytraeidae. A total of 58 samples were taken from a wide diversity of habitat types; 44 enchytraeid taxa were distinguished,
\end{abstract}

* Corresponding author, ttimm@zbi.ee 
40 of them were identified to species level. Twelve nominal species are new for Estonia. Of these two species, one each of Achaeta and Fridericia, are new to science; they are described separately in this volume. Further species new to Estonia are: Bryodrilus ehlersi, Buchholzia fallax, Fridericia argillae, $F$. benti, F. christeri, $F$. maculatiformis, $F$. minor, $F$. rendsinata, $F$. waldenstroemi, and Mesenchytraeus flavus. The taxonomic status of Timmodrilus oligoseta and Achaeta petseri, species newly described for Estonia in previous papers, is uncertain, they are possibly junior synonyms. One tubificid species was found, Rhyacodrilus falciformis, this being the first record of the species from soil in Estonia. Together with previous publications, there are now 46 enchytraeid species recorded from Estonia.

Key words: Enchytraeidae, soil fauna, protected areas, Estonia.

\section{INTRODUCTION}

This paper contains the results of a taxonomic workshop held at the Vorrtsjärv Limnological Station on 15-22 May 2004, following the 6th International Symposium on Enchytraeidae. Apart from taxonomic discussion and training, the objective of the workshop was to deepen the knowledge on the species diversity of enchytraeids in Estonian soils. A considerable contribution in that respect was already made in a previous publication (Dózsa-Farkas et al. 1998), where 33 enchytraeid species were identified from soil samples; Timm (1999) added three more nominal species. The concerted efforts of a substantial portion of the world's enchytraeidologists could not easily top that list within the few days available. Finally, ten more species were discovered, two of them new to science.

\section{MATERIAL AND METHODS}

Samples were taken on excursions to the Alam-Pedja Nature Reserve, Karula National Park, Suur Munamägi Hill (the highest elevation of Estonia), and all around the Võrtsjärv Limnological Station. Sampling sites were selected with a view to maximizing habitat diversity, especially along the moisture and $\mathrm{pH}$ gradients. Samples were taken qualitatively with hand shovels. A sample covered a surface of about 100 to $400 \mathrm{~cm}^{2}$; usually not more than the upper 5 to $10 \mathrm{~cm}$ was removed, roots and vegetation included. Altogether 58 samples were taken. Enchytraeids were extracted from the samples in the laboratory using Graefe's wet/cold extraction method (described in Dunger \& Fiedler 1997). Extraction time varied between 2 and $24 \mathrm{~h}$; the extraction was not meant to be quantitative. Living animals were investigated and identified light-microscopically. About 500 specimens were identified to species level. Reference specimens were fixed in $4 \%$ formol. Soil $\mathrm{pH}$ was determined in a solution containing 1 part of undried soil and 2.5 parts of $\mathrm{H}_{2} \mathrm{O}$ (distilled-deionized). The solution was stirred for several minutes, $\mathrm{pH}$ was measured in the supernatant phase after $2-4 \mathrm{~h}$.

Some reference specimens were whole-mounted and reinvestigated by the first author. Specimens were stained in Paracarmine, passed through an ethanol/xylol 
gradation series, and mounted whole in Malinol, a synthetic substitute for Canada balsam, between two coverslips. They were reinvestigated using a light microscope with interference contrast optics. In addition, four paratype specimens of $A$. petseri from the collection of the Võrtsjärv Limnological Station were reinvestigated.

\section{RESULTS}

Altogether 44 enchytraeid taxa were distinguished, 40 of them were identified to species level ("sp." and "cf." -identifications omitted). Twelve nominal species are new for Estonia, two of them, Achaeta unibulba and Fridericia eiseni, are new to science. They are described separately in this volume (Graefe et al. 2005, Dózsa-Farkas 2005). Further species new to Estonia are: Bryodrilus ehlersi, Buchholzia fallax, Fridericia argillae, F. benti, F. christeri, F. maculatiformis, $F$. minor, F. rendsinata, F. waldenstroemi, and Mesenchytraeus flavus. The actual number of newly discovered species is 10 , because $F$. benti is probably identical with the previously recorded F. bulbosa (Dózsa-Farkas et al. 1998, cf. Schmelz 2003: $117 \mathrm{ff} ., 359 \mathrm{ff}$.), and F. eiseni (Dózsa-Farkas 2005) includes the only record of $F$. sacculata from Estonia. Together with previous publications, there are now 46 nominal enchytraeid species recorded from Estonia. The taxonomic status of Timmodrilus oligoseta and Achaeta petseri, species newly described for Estonia in previous papers, is uncertain, they are possibly junior synonyms (see below, taxonomic remarks). One tubificid species was found, Rhyacodrilus falciformis, this being the first record of the species from soil in Estonia. In the following, the results are presented in three sections: (1) a list of sampling sites with descriptions and species records, (2) a species list with sampling sites, and (3) a section with taxonomic remarks. Humus type terminology in the first section follows Green et al. (1993) and AG Boden (1994).

\section{Description of sampling sites with species records}

Alam-Pedja Nature Reserve, Kirna Nature Trail (17.05.2004)

A1. Floodplain meadow with Trollius europaeus, Filipendula ulmaria. - Fridericia argillae.

A2. Floodplain meadow with Caltha palustris (moister than A1). - Cognettia sphagnetorum, Enchytraeus christenseni, E. buchholzi No. 1, E. buchholzi No. 2., Henlea perpusilla.

A3. Floodplain meadow, closest to the river; Hydromull, pH 6.0 and 7.2 (2 samples). - Cognettia glandulosa, Fridericia bulboides, F. galba, Mesenchytraeus armatus.

A4. Floodplain meadow, at medium distance to the river.-Cognettia glandulosa.

A5. Floodplain meadow, far from the river. - Cognettia glandulosa, Fridericia connata. 
A6. Forest dominated by birch (Betula pendula); soil and litter; Mull, pH 6.0 and 6.8 (2 samples). - Achaeta petseri, Buchholzia appendiculata, Enchytronia parva, Fridericia benti, F. bisetosa, F. galba, Hemifridericia parva, Henlea nasuta, Mesenchytraeus armatus, Timmodrilus oligoseta, Rhyacodrilus falciformis (Tubificidae).

A7. Forest dominated by birch, dead wood, F-Mull (= modermull), pH 4.4. Bryodrilus ehlersi, Buchholzia appendiculata, Cognettia sphagnetorum, Fridericia bisetosa.

A8. Wooded meadow on floodplain; $\mathrm{pH}$ 5.9. - Cernosvitoviella sp., Cognettia sphagnetorum, Marionina argentea.

A9. Aspen (Populus tremula) forest, dead wood; F-Mull (= modermull), pH 4.5. Bryodrilus ehlersi, Buchholzia appendiculata, Cognettia sphagnetorum, Mesenchytraeus armatus, $M$. flavus.

A10. Aspen forest, soil below dead wood; Mull, $\mathrm{pH}$ 6.3. - Bryodrilus diverticulatus, Buchholzia appendiculata, Cognettia sphagnetorum, Enchytraeus buchholzi No. 2, Fridericia benti, F. bulboides, F. minor, Mesenchytraeus armatus.

A11. Aspen forest with lime (Tilia cordata), litter; Mull, pH 7.2. - Buchholzia fallax, Cognettia sphagnetorum, Enchytraeus christenseni, E. buchholzi No. 1, Enchytronia cf. christenseni, Fridericia galba, Hemifridericia parva, Henlea perpusilla.

A12. Near A11, soil; pH 7.2. - Cognettia glandulosa, Enchytraeus buchholzi No. 1, Fridericia galba (dominant), Mesenchytraeus armatus.

A13. Near A11, rotten wood and bark. - Fridericia galba.

A14. Salix sp. bushes, soil below moss; pH 6.6. - Marionina argentea, Rhyacodrilus falciformis (Tubificidae).

A15. Very wet soil at river bank (with sandy cases of Trichoptera); Hydromull, pH 7.1. - Enchytraeus christenseni, E. buchholzi No. 2, Fridericia cf. discifera, Marionina argentea, $M$. riparia.

A16. Similar to A11 and A12, but more sandy; Mull, pH 6.2. - Fridericia bulboides, F. galba.

A17. Wet site at depression in mixed forest, full of detritus, some running water; Hydromull, pH 6.6. - Cognettia glandulosa, Fridericia cf. dozsae, Rhyacodrilus falciformis.

A18. Mixed forest with Mercurialis perennis, close to path; Mull, pH 6.2. Achaeta eiseni, Fridericia galba.

Karula National Park, Ähijärve Nature Trail (19.05.2004)

K1. Moist meadow on the lower lake terrace, black soil, Filipendula ulmaria; Hydromull, pH 5.7. - Buchholzia appendiculata, Fridericia bisetosa, Timmodrilus oligoseta.

K2. Young, sparse alder forest (Alnus incana) with Aegopodium podagraria, Filipendula ulmaria, Urtica dioica; Hydromull, pH 5.7. - Buchholzia appendiculata, Cognettia glandulosa, Fridericia bulboides, Mesenchytraeus sp. juv. 
K3. Spruce forest (Picea abies) on a steep slope; Sorbus aucuparia, Vaccinium myrtillus, Majanthemum bifolium, Oxalis acetosella, Rubus saxatilis, mosses; Moder, $\mathrm{pH}$ 4.6. - Buchholzia appendiculata, Enchytronia parva.

K4. Moist, steep slope near bottom of a ravine in spruce forest (Picea abies); Populus tremula, Sorbus aucuparia, Prunus padus, Anemone nemorosa, Dryopteris linnaeana, Rubus saxatilis, Aegopodium podagraria, Oxalis acetosella, Viola sp., few mosses; Mull, $\mathrm{pH}$ 5.8. - Stercutus niveus.

K5. Heath forest of pine (Pinus sylvestris); Vaccinium vitis-idaea, V. myrtillus, Melampyrum sp., mosses, lichens; Moder, $\mathrm{pH}$ 4.2. - Buchholzia appendiculata.

K6. Moist ravine in mixed spruce forest (Picea abies) with some young Acer platanoides, Alnus incana, Quercus robur; Equisetum sylvestris, Oxalis acetosella, Majanthemum bifolium, Fragaria vesca, Pteridium aquilinum, mosses; Mullmoder, pH 4.7. - Fridericia bulboides, F. connata, Mesenchytraeus armatus, Stercutus niveus.

K7. At Ähijärve bus stop, slight slope, dry; abandoned field spontaneously developing into meadow; Taraxacum sp., grasses, Fragaria vesca; Mull, pH 5.5. - Fridericia bulboides, $F$. connata, F. minor, Henlea ventriculosa.

Võrtsjärv Limnological Station (15.-19.05.2004). Samples Nos L1-L4, L8, and L10 belong to the Petseri group of the Station's dwelling houses

L1. Spruce forest with interspersed Sorbus aucuparia, flat heap of birch leaves ( $2 \mathrm{~m}$ from a forest path); Mull, pH 7.1. - Bryodrilus ehlersi, Buchholzia appendiculata, Enchytraeus christenseni, E. buchholzi No. 1, Fridericia bisetosa, F. paroniana, F. perrieri, Marionina communis.

L2. Mixed forest (only Betula pendula inside $4 \mathrm{~m}$ radius, Sorbus aucuparia and Picea abies on perimeter), upper $5 \mathrm{~cm}$ of litter, moss, and soil; Mull, pH 6.5. - Achaeta unibulba, Bryodrilus diverticulatus, Buchholzia fallax, Cognettia sphagnetorum, Enchytraeus buchholzi No. 2, E. buchholzi No. 3, Enchytronia parva, Fridericia benti, F. bulboides, F. ratzeli, Henlea glandulifera, Hemifridericia sp., Stercutus niveus, Timmodrilus oligoseta.

L3. (= L-9 in Dózsa-Farkas et al. 1998). Alder carr (Alnus glutinosa) near lake shore, water-logged soil, but surface dry; Hydromull, pH 7.2. - Buchholzia fallax, Enchytraeus christenseni, Fridericia eiseni, F. perrieri, Hemifridericia parva, Mesenchytraeus armatus.

L4. (= L-10 in Dózsa-Farkas et al. 1998). Orchard No. 1, grass sod with sandy soil; Mull, pH 7.3. - Achaeta petseri, Bryodrilus ehlersi, Enchytraeus buchholzi No. 1, Fridericia bisetosa, F. christeri, F. eiseni, F. galba, F. maculatiformis, $F$. paroniana, Henlea ventriculosa.

L5. Lake shore right above water mark, grass roots; pH 3.7. - Buchholzia appendiculata.

L6. Lawn in front of the main building of Limnological Station; Mull, pH 6.5. Fridericia galba, F. rendsinata. 
L7. (= L-5 in Dózsa-Farkas et al. 1998). $2 \mathrm{~km}$ east of the Limnological Station, pine heath forest on old dunes, Mor. - Cognettia sphagnetorum, Mesenchytraeus flavus.

L8. (= L-8 in Dózsa-Farkas et al. 1998). Moist meadow with grasses, herbs, and small bushes; Mull, pH 6.9. - Buchholzia appendiculata, Fridericia argillae, Timmodrilus oligoseta.

L9. Mixed wood north of Limnological Station, with Galeobdolon luteum, Hepatica nobilis, Anemone nemorosa; Mull, $\mathrm{pH}$ 4.7. - Buchholzia appendiculata, Cognettia sphagnetorum, Fridericia bisetosa, F. connata, F. paroniana, Stercutus niveus.

L10. (= L-10 in Dózsa-Farkas et al. 1998). Near L4, orchard No. 1, grass sod with sandy soil; Mull, pH 6.5. - Buchholzia appendiculata, Enchytraeus buchholzi No. 2.

L11. South of main building of Limnological Station, mixed forest of spruce, birch, and aspen; mosses and Aegopodium podagraria; Mull, pH 6.0. - Buchholzia appendiculata, Enchytraeus bulbosus.

Palupõhja (southern portion of the Alam-Pedja Nature Reserve) (21.05.2004)

P1. Near Kahu Farm, pine forest, moss carpet, Vaccinium myrtillus, V. vitis-idaea; Mor, $\mathrm{pH}$ 3.5. - Cognettia sphagnetorum.

P2. Road ditch, bog with floating Sphagnum sp. and Eriophorum sp.; pH 4.0. - Cognettia sphagnetorum.

P3. Selli-Sillaotsa Nature Trail: bog island with peaty soil and pine forest, mosses, Sphagnum sp., Vaccinium myrtillus, V. vitis-idaea, young birches; pH 3.6. - Cognettia sphagnetorum.

P4. Selli-Sillaotsa Nature Trail: wet transition bog with Sphagnum sp. and Carex sp.; pH 6.0. - Cernosvitoviella sp., Cognettia glandulosa, C. sphagnetorum, Enchytraeus buchholzi No. 2, Henlea ventriculosa, Hemifridericia sp., Marionina argentea, Mesenchytraeus armatus.

Suur Munamägi Hill, the highest elevation (318 m a.s.l.) of Estonia (19.05.2004)

S1. Mixed spruce forest on path to hilltop; Picea abies, Sorbus aucuparia, Acer platanoides, Oxalis acetosella, Anemone nemorosa; pH 5.2. - Achaeta unibulba, Buchholzia fallax, Enchytraeus buchholzi No. 2, Enchytronia parva, Fridericia benti, F. bisetosa, F. galba, Mesenchytraeus armatus.

S2. Near and similar to S1, further downslope; $\mathrm{pH}$ 6.2. - Fridericia waldenstroemi, Stercutus niveus.

Tamme Cliff on the eastern shore of Lake Võrtsjärv, hiking trail along the cliff foot, in shadow of trees (21.05.2004)

T1. Slope with rich black soil, Aegopodium podagraria, Urtica dioica, Chelidonium majus, Taraxacum sp., Ribes nigrum; pH 7.5. - Cognettia sphagnetorum, Fridericia connata, F. galba, F. maculatiformis, F. rendsinata, Stercutus niveus. 
T2. Moss-covered, rotting wood (Salix fragilis) among grasses on wet soil; $\mathrm{pH}$ 6.2. - Hemifridericia parva.

T3. Wet soil under large Salix fragilis and Alnus glutinosa with Urtica dioica, Impatiens parviflora, Ribes nigrum, Humulus lupulus, young Populus tremula; $\mathrm{pH}$ 6.3. - Bryodrilus diverticulatus, Fridericia galba, Henlea glandulifera, H. perpusilla, H. ventriculosa, Marionina communis.

\section{Species list with numbers of specimens (spms) identified, sampling sites, and the $\mathrm{pH}$ range of the sites where the species was found}

$!=$ Species new for Estonia ("cf."-identifications not included). (!) = New record for Estonia, but species has been recorded previously under a different name. $*$ See taxonomic remarks.

Achaeta eiseni Vejdovský, 1878 (2 spms). - A18. - pH 6.2

* Achaeta petseri Dózsa-Farkas, 1998 (4 spms). - A6, L4. - pH 6.2-7.3

! Achaeta unibulba Graefe, Dózsa-Farkas \& Christensen, 2005 (see species description in this volume) (5 spms). - L2, S1. - pH 5.2-6.2

Bryodrilus diverticulatus Cernosvitov, 1929 (4 spms). - A10, L2, T3. - pH 6.3-6.5

! Bryodrilus ehlersi Ude, 1892 (7 spms). - A7, A9, L1, L4. - pH 4.4-7.3

Buchholzia appendiculata (Buchholz, 1862) (>74 spms). - A6, A7, A9, A10, K1, K2, K3, K5, L1, L5, L8, L9, L10, L11. - pH 3.7-7.5

! Buchholzia fallax Michaelsen, 1887 (4 spms). - A11, L2, L3, S1. - pH 6.5-7.2

Cernosvitoviella sp. (2 spms). - A8, P4. - pH 5.9-6.0

Cognettia glandulosa (Michaelsen, 1888) (8 spms). - A3, A4, A5, A12, A17, K2, P4. - pH 5.7-7.2

Cognettia sphagnetorum (Vejdovský, 1878) (>84 spms). - A2, A7, A9, A10, A11, L2, L7, L9, P1, P2, P3, P4, T1. - pH 3.5-7.5

* Enchytraeus buchholzi Vejdovský, 1878 (24 spms). - A2, A10, A11, A12, A15, L1, L2, L3, L4, L10, P4, S1. - pH 5.2-7.3

Enchytraeus bulbosus Nielsen \& Christensen, 1963 (1 spm). - L11. - pH 6.0

* Enchytraeus christenseni Dózsa-Farkas, 1992 (6 spms). - A2, A11, A15, L1, L3. $-\mathrm{pH} 7.1-7.4$

Enchytronia parva Nielsen \& Christensen, 1959 (12 spms). - A6, K3, L2, S1. $\mathrm{pH} 4.6-6.8$

* Enchytronia cf. christenseni Dózsa-Farkas, 1970 (1 spm). - A11. - pH 7.2

! Fridericia argillae Schmelz, 2003 (3 spms). - A1, L8. - pH 6.9

(!) Fridericia benti Schmelz, $2003(?=F$. bulbosa in Dózsa-Farkas et al. 1998)

(6 spms). - A6, A10, L2, S1. - pH 5.2-6.8

Fridericia bisetosa (Levinsen, 1884) (36 spms). - A6, A7, K1, L1, L4, L9, S1. pH 4.4-7.3

Fridericia bulboides Nielsen \& Christensen, 1959 (13 spms). - A3, A10, A16, K2, K6, K7, L2. - pH 4.7-7.2

! Fridericia christeri Rota \& Healy, 1999 (1 spm). - L4. - pH 7.3 
Fridericia connata Bretscher, 1902 (11 spms). - A5, K6, K7, L9, T1. - pH 4.7-7.5 (!) Fridericia eiseni Dózsa-Farkas, 2005 (=F. sacculata Bell, 1936 in DózsaFarkas et al. 1998) (3 spms). - L3, L4. - pH 7.2-7.3

Fridericia galba (Hoffmeister, 1843) (>30 spms). - A3, A6, A11, A12, A16, A18, L4, L5, S1, T1, T3. - pH 5.2-7.5

! Fridericia maculatiformis Dózsa-Farkas, 1972 (2 spms). - L4, T1. - pH 7.3-7.5

!* Fridericia minor Friend, 1913 (=F.gracilis Bülow, 1957) (4 spms). - A10, K7. - $\mathrm{pH} 4.7-6.3$

Fridericia paroniana Issel, 1904 (3 spms). - L1, L4, L9. - pH 4.7-7.3

Fridericia perrieri (Vejdovský, 1878) (2 spms). - L1, L3. - pH 7.3

* Fridericia ratzeli (Eisen, 1872) (1 spm). - L2. - pH 6.5

! Fridericia rendsinata Dózsa-Farkas, 1972 (12 spms). - L6, T1. - pH 6.5-7.5

! Fridericia waldenstroemi Rota \& Healy, 1999 (4 spms). - S2. - pH 6.2

* Fridericia cf. discifera Healy, 1975 (1 spm). - A15. - pH 7.1

* Fridericia cf. dozsae Schmelz, 2003 (1 spm). - A17. - pH 6.6

Hemifridericia parva Nielsen \& Christensen, 1959 (7 spms). - A6, A11, L3, T2. - pH 6.2-7.2

* Hemifridericia sp. (3 spms). - L2, P4. - pH 6.0

Henlea glandulifera Nurminen, 1970 (13 spms). - L2, T3. - pH 6.3-6.5

Henlea nasuta (Eisen, 1878) (1 spm). - A6. - pH 6.0-6.8

Henlea perpusilla Friend, 1911 (5 spms). - A2, A11, L2, T3. - pH 6.3-7.2

Henlea ventriculosa (Udekem, 1854) (6 spms). - K7, L4, P4, T3. - pH 4.7-7.3

Marionina argentea (Michaelsen, 1889) (5 spms). - A8, A14, A15, P4. pH 5.9-7.1

Marionina communis Nielsen \& Christensen, 1959 (8 spms). - L1, T3. - pH 6.3-7.1

Marionina riparia Bretscher, 1899 (1 spm). - A15. - pH 7.1

Mesenchytraeus armatus (Levinsen, 1884) (38 spms). - A3, A6, A9, A10, A12, K6, L3, P4, S1. - pH 4.5-7.2

! Mesenchytraeus flavus (Levinsen, 1884) (2 spms). - A9, L7. - pH 4.5

Stercutus niveus Michaelsen, 1888 (16 spms). - K4, K6, L2, L9, S2, T1. $\mathrm{pH} 4.7-7.5$

* Timmodrilus oligoseta Dózsa-Farkas, 1997 (6 spms). - A6, K1, L2, L8. pH 5.7-6.9

Rhyacodrilus falciformis Bretscher, 1901 (Tubificidae; the first record from soil in Estonia) (3 spms). - A6, A14, A17. - pH 5.6-6.8

\section{Taxonomic remarks (by R. M. Schmelz)}

Achaeta petseri Dózsa-Farkas, 1998

$=$ ? Achaeta pannonica Graefe, 1989

Investigated material: One mature specimen, investigated alive and as whole mount, first in glycerine, later in Malinol. Four paratype specimens, unnumbered, collection of the Võrtsjärv Limnological Station, unstained whole-mounts, all submature, one with almost developed clitellum. 
The specimen collected at the type locality and identified as A. petseri differs in two characters from the original description: (1) secondary pharyngeal gland lobes are present in segments V and VI; (2) all sexual organs except the spermathecae are shifted one segment forward, the male pore is accordingly located in $\mathrm{XI}$ and not in XII as usual. Both characters are also present in the reinvestigated paratype specimens of $A$. petseri. Size, shape, and location of secondary pharyngeal glands is similar to a figure in Graefe (1980: Fig. 4), where the pharyngeal glands of $A$. camerani (Cognetti, 1899) are illustrated.

The absence of secondary ventral pharyngeal gland lobes was among the principal characters that distinguished the new species from a group of morphologically similar Achaeta species, namely A. camerani (Cognetti, 1899), A. brevivasa Graefe, 1980, A. iberica Graefe, 1989, A. pannonica Graefe, 1989, A. etrusca Rota, 1995, and A. afolliculata Sesma \& Dózsa-Farkas, 1993 (Dózsa-Farkas in Dózsa-Farkas et al. 1998). This group is characterized by short spermathecae with lateral ectal openings and by the absence of bottle-shaped glands, termed setal follicles in the older literature; with the exception of $A$. camerani, they are also fairly small species, measuring only $3-4 \mathrm{~mm}$ in length. In this group, a displacement of the sexual organs one segment anteriad is also described for A. pannonica. Therefore a discussion of $A$. petseri and A. pannonica is necessary.

The similarity of $A$. petseri and $A$. pannonica includes the following characters: dorsal blood vessel origin (in VII), number and position of preclitellar nephridia (3 pairs, from 6/7 to 8/9), and shape and size of the male reproductive system. Even a narrow mid-dorsal gap in the clitellum, originally described for A. pannonica, is present in the A.petseri specimens investigated here. The two species differ in three characters: (1) Septa are thin throughout in A. petseri, whereas in A. pannonica the septa 4/5-7/8 are thickened. (2) Coelomocytes are elongately oval in $A$. petseri and rounded in A pannonica. (This character is derived from the original description of $A$. petseri; the single specimen sampled had rounded coelomocytes.) (3) The hyaline clitellar gland cells of $A$. pannonica are arranged in eight longitudinal rows dorsally; in the types and reference specimens of $A$. petseri, the dorsal hyalocytes are arranged irregularly; there is some longitudinal arrangement, but separate and countable rows are not present. This character is not dealt with in the original description of $A$. petseri. All three differences may be artificial, i.e. due to different modes of description or observation errors. The lens-shaped epidermal glands may provide a further difference. In A. pannonica, these cells are conspicuous and readily distinguished in living specimens (U. Graefe and R. M. Schmelz, pers. obs.); in A. petseri, they are inconspicuous according to the original account, and they were not seen in living animals during the taxonomic workshop (but not particularly looked for, either). They are also invisible in the investigated paratype specimens. However, the cells show well in a few anterior and posterior segments of the single whole-mounted workshop reference specimen of A. petseri (microscope with interference contrast optics) and their arrangement is exactly as figured for A. pannonica in Graefe (1989: Fig. 1), except that the ventral cells were not seen.

To summarize, regarding the slightness of differences between $A$. petseri and A. pannonica, it seems possible that the former is a junior synonym of the latter. 


\section{Enchytraeus buchholzi Vejdovský, 1878}

The specimens identified here as E. buchholzi share the following characters: Body length below $1 \mathrm{~cm}$. Segment number below 32. Two and three chaetae per bundle. Oesophageal appendages long and much coiled. Pharyngeal glands all separate dorsally. Four pairs of preclitellar nephridia, from 6/7 to $9 / 10$. Clitellum not developed ventrally. Seminal vesicle small, dorsally in XI, extending over $1 / 2$ segment, or shorter. Sperm funnel small, length less than $1 / 2$ body diameter. Male copulatory organ small, globular, not floppy. Spermathecal ectal duct short.

The material is heterogeneous; three forms were recognized, distinguishable as follows.

Form No. 1 (sites A2, A11, A12, L1, L4): Coelomocytes without refractile vesicles, clitellum cells in rows, ventrally not developed. Spermatheca: short ectal duct, fully glandular, not wider than ampulla, ampulla almost globular, slightly longer than wide, ental duct as long as ectal duct plus ampulla.

Form No. 2 (sites A2, A10, A15, L2, L10, P4, S1): Coelomocytes with numerous, small refractile granules; cell aggregations dark grey. Clitellum cells in rows, ventrally not developed. Spermatheca: short ectal duct, fully glandular, not wider than ampulla, ampulla almost globular or onion-shaped, slightly elongate, length of ental duct variable.

Form No. 3 (site L3): Coelomocytes with sparse refractile vesicles, cell aggregations not dark grey, clitellar gland cells not in rows. Spermatheca with short glandular ectal duct and globular or spindle-shaped ampulla, length of ental duct not seen.

Records of E. buchholzi often comprise heterogeneous material. Usually two forms are recognized, distinguished by the presence or absence of refractile granules on the coelomocytes, but the variation comprises also body length, segment number, size and shape of sperm funnel, and shape of the spermatheca. The variation range of characters accepted for this nominal species varies among authors and appears to depend on the material at hand. It is usually assumed that $E$. buchholzi consists of several species (e.g. Rota \& Healy 1994) rather than that there is just one, highly variable species. Protein-analytical methods have detected genetically distinct groups (Brockmeyer 1991), and some of them have been delineated as new species (Westheide \& Graefe 1992). The complex itself was addressed in Schmelz et al. (1999) with morphology, isozymes, and cross-breeding tests but not resolved taxonomically. Schmelz \& Collado (1999) delineated one species out of this group (E. luxuriosus) using morphological characters alone and pointed to differences between the original description of E. buchholzi by Vejdovský (1878) and the redescription in Nielsen \& Christensen (1959), to which most of the following accounts refer.

Enchytraeus christenseni Dózsa-Farkas, 1992

=Enchytraeus minutus Nielsen \& Christensen, 1961

The specimens agree exactly with the original description. Notable are the following characters: (1) spermatheca with long ectal duct, completely and regularly glandular; (2) ampulla spherical; (3) ental duct short; (4) coelomocytes 
with few coarse refractile granules. Furthermore, the Estonian specimens were found at fairly wet sites, which agrees with the type locality.

\section{Enchytronia cf. christenseni Dózsa-Farkas, 1970}

The single living specimen from site A11 was identified as E. christenseni on account of the large size of the intestinal diverticula and the spermathecal ectal glands. The reinvestigation of the whole-mounted specimen revealed the following differences from the original description (Dózsa-Farkas 1970): (1) only one row of epidermal gland cells, cells oblong and large (vs. glands minute, in 3-4 rows per segment); (2) spermathecae fused proximally (vs. spermathecae separate). The identity of this specimen remains therefore uncertain.

The mature specimen has a clitellum that is developed only laterally; the ventral gap is as wide as the distance between the bursal slits of the male copulatory organs; the dorsal gap is even wider. This character is not dealt with in the original description; however, it is also found in other species of Enchytronia, e.g. in E. parva (R. M. Schmelz, pers. obs.).

The specimen differs from the previously recorded E. parva (Dózsa-Farkas et al. 1998) in the shape of the intestinal diverticula: large ovoid bodies occupying the entire segment, situated laterally of the oesophagus, seemingly independent of it, and overlapping dorsally. In E. parva, the intestinal diverticula are smaller and actually not more than an enlargement of the intestine in the anterior of VI. This specimen belongs therefore to a species that is new to Estonia.

Fridericia minor Friend, 1913

$=$ Fridericia gracilis Bülow, 1957

Schmelz (2003: 244-245) distinguished three forms with unknown taxonomic status in this species. The Estonian specimens belong to form B, recorded so far only from Sweden (Rota \& Healy 1999) and northern Germany (Schmelz 2003). It is distinguishable from the other two forms mainly by dorsally connected pharyngeal gland lobes, a-type coelomocytes, nephridia at 10/11, a large spermathecal ectal gland, and pear-shaped diverticula.

\section{Fridericia ratzeli (Eisen, 1872)}

This often-cited species is a complex of different cytotypes (Nielsen \& Christensen 1959) and parthenogenetic lineages among sexual species (Christensen 1961). Schmelz (2003: 305-306) found no consistent clues to separate species within this group, and established many new junior synonyms, among them F. sacculata, previously recorded from Estonia (species record with a question mark in Dózsa-Farkas et al. 1998). However, Dózsa-Farkas (2005) describes a new species from this complex (as $F$. eiseni, see description in this volume) and includes the previous record of $F$. sacculata.

Fridericia cf. discifera Healy, 1975

One juvenile specimen with 2 chaetae per bundle. Non-sexual characters agree with $F$. discifera as redescribed in Schmelz (1999), especially regarding the 
number, shape, and texture of the nucleated coelomocytes: few cells, cells twice as long as wide, almost hyaline, cell periphery lined with small refractile vesicles. This character combination is peculiar in the genus. F. discifera has so far not yet been recorded from Estonia; this would be the northernmost record of the species. The species record remains unconfirmed until mature specimens are found.

Fridericia cf. dozsae Schmelz, 2003

The single specimen sampled at site A17 is submature, without clitellum. It agrees with $F$. dozsae in most characters, especially in details of the pharyngeal glands, the male reproductive system, the spermatheca, and in the habitat type (moist to wet soils). It differs in smaller body size and lower segment number (42). These differences may be ascribed to the submature state of the individual; however, the species record cannot be confirmed unless fully mature specimens have been found.

\section{Hemifridericia sp.}

Several specimens did not entirely match the description of $H$. parva. In one specimen, the lenticytes (= anucleate coelomocytes) were not observed; in another, there were 3 chaetae per bundle ventrally in II; a third specimen had nephridia with abnormally thick interstitial tissue. It remained undecided whether these specimens were aberrant forms of $H$. parva or members of a new species.

Timmodrilus oligoseta Dózsa-Farkas, 1997

$=$ ? Fridericia maculata Issel, 1905

Investigated material: Four specimens from type locality, investigated as living animals and in preserved state (whole-mounted first in glycerin, later in Malinol).

The genus Timmodrilus was erected (Dózsa-Farkas 1997) for a species found in Estonia that highly resembled Fridericia but that lacked segmental dorsal pores. Segmental dorsal pores are among the main diagnostic characters of Fridericia; they occur in all species of the genus and only in this genus. The species was named $T$. oligoseta with reference to the lack of lateral chaetae in anterior segments. (The chaetal formula is $0-0.2: 2-2$.) However, Schmelz (2003: 61-62) considered the new genus not well-founded, arguing that a reduction of dorsal pores may have occurred convergently several times in the evolution of the large genus Fridericia, together (and functionally correlated) with a thickening of the cuticle and a reduction of chaetal numbers, especially in lateral positions. Thick cuticle and reduction of chaetal numbers co-occur in several Fridericia species, for example in F. reducata Dózsa-Farkas, 1974, F. semisetosa Dózsa-Farkas, 1970, F. maculata Issel, 1905, and F. paraunisetosa Xie, Liang \& Wang, 2000. In the last species, a thick cuticle is not originally described but present in a paratype specimen (R. M. Schmelz, pers. obs.); furthermore, F. paraunisetosa lacks dorsal pores in several positions, which further blurs the distinction between Timmodrilus and Fridericia (Schmelz 2003: 62).

During this workshop, the type locality of $T$. oligoseta was resampled and mature specimens with a fully developed clitellum were found. These specimens 
show highest similarity of $T$. oligoseta to $F$. maculata as redescribed in Schmelz (2003: 230-235), down to such details as coelomocyte texture and distribution pattern of clitellar gland cells. Furthermore, some of the collected specimens appeared to possess rudimentary, i.e. non-functional, dorsal pores in some segments. Hence, $T$. oligoseta is probably a junior synonym of $F$. maculata.

It should be noted, however, that F. maculata as conceived in Schmelz (2003) comprises three different forms, distinguishable only by the chaetal patterns: (1) the original form with 2 chaetae per bundle throughout; (2) an often-described variant with a maximum of 4 chaetae per bundle; and (3) a variant originally described as a separate species under the name of $F$. renatae (Möller 1971), with a reduced set of lateral chaetae like $T$. oligoseta. The incorporation of $T$. oligoseta into F. maculata would add a fourth variant, characterized by the absence (or reduction) of segmental dorsal pores, everything else being indistinguishable from the renatae form. The taxonomic status of these four variants is still unknown (Schmelz 2003) and must be reinvestigated with molecular methods. They may turn out as environmental modifications, as geographical races, or as separate taxa on the subspecies or even species level.

\section{DISCUSSION}

Altogether, 46 enchytraeid species are now recorded from Estonia. The number will certainly increase when more habitat types are included. For example, marine littoral sites were not sampled, and strongly acid mineral soil sites are not well represented here. The species number is lower than, for example, in Sweden, where up to now 94 species have been recorded (Rota et al. 1998). A lower number of species is generally to be expected in a smaller country with a comparatively uniform geology and topography. However, it will take much effort to determine which of the species not recorded are in fact not present in Estonia. We are still very far from being capable of outlining reliable distribution boundaries of most of the enchytraeid species.

The species composition reflects largely the common North-Western and Central European fauna. Exceptions are Bryodrilus diverticulatus and Henlea glandulifera, which represent a truly northern element. So far $B$. diverticulatus has been recorded only from Greenland (Černosvitov 1929) and the Russian Palaearctic (Christensen \& Dózsa-Farkas 1999). It is absent in the lists of Swedish enchytraeids (Rota et al. 1998, Erséus et al. 1999); the Estonian record is the southernmost so far. Henlea glandulifera has an arctic-alpine distribution (Rota et al. 1998).

A few species are not common. Fridericia rendsinata was so far known only from Hungary (type locality) and Austria (Bauer 1996). Fridericia argillae has been recorded here for the first time after the original description. Timmodrilus oligoseta and Achaeta petseri are only known from Estonia. However, they may be junior synonyms of species with a wider geographic distribution; this includes 
the possibility of subspecies or geographical races. On the other hand, some species appear to be rarer in Estonia than in North-Western and Central Europe. Taken together with previous published records (Dózsa-Farkas et al. 1998, Timm 1999), the apparent absence of Marionina clavata and Achaeta affinis in acid soils and the comparative rarity of Fridericia perrieri from moist-wet habitats are worth mentioning, even though definitive statements require more intensive sampling.

Regarding species assemblages and ecological behaviour, we have a picture similar to that in North-Western and Central Europe. For example, species with moisture figure above 5 in Graefe \& Schmelz (1999) (moist to wet conditions) were found here in moist to wet (or at least temporarily wet) soils, too: Cernosvitoviella sp., Cognettia glandulosa, Marionina argentea, Marionina riparia, Mesenchytraeus armatus, and the tubificid Rhyacodrilus falciformis. Estonian enchytraeid communities are both species-rich and Fridericia-dominated at slightly acid to neutral and not water-saturated sites (e.g. sites A6, A10, A11, L4, T1), and species-poor and Cognettia sphagnetorum-dominated at acid sites (sites L7, P1-P3), irrespective of the moisture regime, i.e. the sites can be wet (site P2) or dry (site L7). Regarding soil $\mathrm{pH}$ it seems noteworthy that several species with reaction figure 7 in Graefe \& Schmelz (1999) ("indicator of slightly acid to slightly alkaline conditions, never in strongly acid soils") were found in several samples with the $\mathrm{pH}$ below 5: Buchholzia appendiculata, Fridericia bisetosa, F. bulboides, F. connata, Mesenchytraeus armatus, and Stercutus niveus. An exchange of the fauna from a species-rich and Fridericia-dominated assemblage to a Cognettia sphagnetorum-dominated assemblage takes place at about $\mathrm{pH} 4.2$ $\left(\mathrm{CaCl}_{2}\right)(\mathrm{Graefe}$ et al. 2002). This threshhold value is considerably higher when the $\mathrm{pH}$ is measured with $\mathrm{H}_{2} \mathrm{O}$ (Healy 1980). However, in the Estonian samples the threshhold $\mathrm{pH}$ appears to be 4.5 or even lower, even though it was measured with $\mathrm{H}_{2} \mathrm{O}$. This may express a shift in the ecological behaviour of the species; its possible correlation with climatic and geological factors in Estonia deserves further studies.

\section{ACKNOWLEDGEMENTS}

We thank Brenda Healy and Emilia Rota for critically reviewing the manuscript and for useful suggestions that improved the paper.

\section{REFERENCES}

AG Boden. 1994. Bodenkundliche Kartieranleitung, 4th Ed. (KA4). Hannover.

Bauer, R. 1996. Die Enchytraeiden-Gemeinschaften (Oligochaeta) auf Ackerflächen unter verschiedenen Anbaumaßnahmen. Mitt. Deutsch. Bodenkundl. Ges., 81, 249-252.

Brockmeyer, V. 1991. Isozymes and general protein patterns for use in discrimination and identification of Enchytraeus species (Annelida, Oligochaeta). Z. zool. Syst. Evolut.-forschg., 29, 343-361.

Černosvitov, L. 1929. Communication préliminaire sur les Oligochètes récoltés par M. P. Remy pendant la croisière arctique effectuée par le "Pourquoi-Pas?" en 1926 sous la direction du Dr. J.-B. Charcot. Bull. Mus. Nat. Hist. Nat., 21(2), 144-149. 
Christensen, B. 1961. Studies on cyto-taxonomy and reproduction in the Enchytraeidae. Hereditas, 48, 387-449.

Christensen, B. \& Dózsa-Farkas, K. 1999. The enchytraeid fauna of the Palearctic tundra (Oligochaeta, Enchytraeidae). Biol. Skr. Dan. Vid. Selsk., 52, 1-37.

Dózsa-Farkas, K. 1970. The description of three new species and some data to the enchytraeid fauna of the Baradla Cave, Hungary. Opusc. Zool. Budapest, 10, 241-251.

Dózsa-Farkas, K. 1997. Timmodrilus gen. n., a new genus from the family Enchytraeidae (Oligochaeta). Opusc. Zool. Budapest, 29-30, 49-52.

Dózsa-Farkas, K. 2005. Fridericia eiseni sp. n., a new enchytraeid species from the Fridericia ratzeli species group. Proc. Estonian Acad. Sci. Biol. Ecol., 54, 279-291.

Dózsa-Farkas, K., Rota, E., Healy, B. \& Timm, T. 1998. Estonian Enchytraeidae (Oligochaeta) 1. Terrestrial Enchytraeidae from the Võrtsjärv Limnological Station and from Puurmani. Proc. Estonian Acad. Sci. Biol. Ecol., 47, 235-246.

Dunger, W. \& Fiedler, H. J. (eds.) 1997. Methoden der Bodenbiologie. Gustav Fischer, Jena.

Erséus, C., Grimm, R., Healy, B., Lundberg, S., Rota, E. \& Timm, T. 1999. Clitellate diversity in Nationalstadsparken, an urban national park in Stockholm, Sweden. Hydrobiologia, 406, $101-110$.

Graefe, U. 1980. Systematische Untersuchungen an der Gattung Achaeta (Enchytraeidae, Oligochaeta). 1. Beschreibung von Achaeta brevivasa sp. n. und Achaeta camerani (Cognetti). Mitt. hamb. zool. Mus. Inst., 77, 35-39.

Graefe, U. 1989. Systematische Untersuchungen an der Gattung Achaeta (Enchytraeidae, Clitellata). 2. Beschreibung von vier neuen Arten. Mitt. hamb. zool. Mus. Inst., 86, 127-131.

Graefe, U. \& Schmelz, R. M. 1999. Indicator values, strategy types and life forms of terrestrial Enchytraeidae and other microannelids. In Newsletter on Enchytraeidae No. 6. Proceedings of the 3rd International Symposium on Enchytraeidae, Osnabrück, Germany: 3-4 July 1998 (Schmelz, R. M. \& Sühlo, K., eds.), pp. 59-67. Universitätsverlag Rasch, Osnabrück, Germany.

Graefe, U., Elsner, D.-Ch., Gehrmann, J. \& Stemplemann, I. 2002. Schwellenwerte der Bodenversauerung für die Bodenbiozönose. Mitt. Deutsch. Bodenkundl. Ges., 98, 39-40.

Graefe, U., Dózsa-Farkas, K. \& Christensen, B. 2005. Achaeta unibulba sp. n., a widespread European species (Oligochaeta, Enchytraeidae). Proc. Estonian Acad. Sci. Biol. Ecol., 54, 271-278.

Green, R. N., Trowbridge, R. L. \& Klinka, K. 1993. Towards a taxonomic classification of humus forms. Forest Sci. Monogr., 29, 1-49.

Healy, B. 1980. Distribution of terrestrial Enchytraeidae in Ireland. Pedobiologia, 20, 159-175.

Möller, F. 1971. Systematische Untersuchungen an terricolen Enchytraeiden einiger Grünlandstandorte im Bezirk Potsdam. Mitt. Zool. Mus. Berlin, 47, 131-167.

Nielsen, C. O. \& Christensen, B. 1959. The Enchytraeidae. Critical revision and taxonomy of European species (Studies on Enchytraeidae VII). Nat. Jutl., 8-9, 1-160.

Rota, E. \& Healy, B. 1994.The enchytraeid fauna of North Africa. Hydrobiologia, 278, 53-66.

Rota, E. \& Healy, B. 1999. A taxonomic study of some Swedish Enchytraeidae (Oligochaeta), with descriptions of four new species and notes on the genus Fridericia. J. Nat. Hist., 33, 29-64.

Rota, E., Healy, B. \& Erséus, C. 1998. Biogeography and taxonomy of terrestrial Enchytraeidae (Oligochaeta) in Northern Sweden, with comparative remarks on the genus Henlea. Zool. Anz., 237, 155-169.

Schmelz, R. M. 1999. On the combined use of morphological and protein patterns in Enchytraeidae species level taxonomy: Example Fridericia discifera Healy, 1975. Pedobiologia, 43, 497506.

Schmelz, R. M. 2003. Taxonomy of Fridericia (Oligochaeta, Enchytraeidae). Revision of species with morphological and biochemical methods. Abh. Naturw. Ver. Hamburg (NF), 38.

Schmelz, R. M. \& Collado, R. 1999. Enchytraeus luxuriosus sp. nov., a new terrestrial oligochaete species (Enchytraeidae, Clitellata, Annelida). Carolinea, 57, 93-100. 
Schmelz, R. M., Collado, R. \& Oestreich, M. 1999. The Enchytraeus buchholzi/christenseni species complex - outline of a problem and first steps towards a solution. In Newsletter on Enchytraeidae No. 6. Proceedings of the 3rd International Symposium on Enchytraeidae, Osnabrück, Germany: 3-4 July 1998 (Schmelz, R. M. \& Sühlo, K., eds.), pp. 31-39. Universitätsverlag Rasch, Osnabrück, Germany.

Timm, T. 1999. A Guide to the Estonian Annelida. Estonian Academy Publishers, Tartu-Tallinn.

Vejdovský, F. 1878. Zur Anatomie und Systematik der Enchytraeiden. Sitzb. K. Böhm. Ges. Wiss., 1877, 294-304.

Westheide, W. \& Graefe, U. 1992. Two new terrestrial Enchytraeus species (Oligochaeta, Annelida). J. Nat. Hist., 26, 479-488.

\section{Eesti valgeliimuklased (Oligochaeta: Enchytraeidae) 2. Mais 2004 peetud faunistiliste teadustalgute tulemused}

Rüdiger M. Schmelz, Naime Arslan, Roswitha Bauer, Wim Didden, Klára Dózsa-Farkas, Ulfert Graefe, Irina Panchenko, Andrei Pokarzhevski, Jörg Römbke, Jiřri Schlaghamerský, Łukasz Sobczyk, Zoltán Somogyi, Valerie Standen, Astrid Thompson, Jānis Ventiņš ja Tarmo Timm

Teadustalgud toimusid 15.-22. mail 2004 Võrtsjärve Limnoloogiajaamas pärast 6. rahvusvahelist valgeliimuklaste-alast sümpoosioni. Mitmesugustest elupaikadest Lõuna-Eestis, sealhulgas Alam-Pedja looduskaitsealalt, Karula Rahvuspargist ja Võrtsjärve kaldalt, kogutud 58 proovist leiti 44 liiki valgeliimuklasi; neist 40 õnnestus määrata liigini. 12 nominaalset liiki on Eestile uued: Bryodrilus ehlersi, Buchholzia fallax, Fridericia argillae, F. benti, F. christeri, F. maculatiformis, $F$. minor, F. rendsinata, F. waldenstroemi, Mesenchytraeus flavus ja veel kaks teadusele uut liiki, mida on kirjeldatud käesoleva erinumbri eri artiklites. Kaks varem Eestist uutena kirjeldatud liiki, Timmodrilus oligoseta ja Achaeta petseri, võivad olla kehtetud kui nooremad sünonüümid. Leiti ka üks mudatuplaste sugukonna liik, Rhyacodrilus falciformis, seda Eestis esmakordselt mullast. Koos kõigi varasemate töödega on nüüd Eestist teada 46 liiki valgeliimuklasi. 